\section{J I T A A}

Journal of the Indonesian Tropical Animal Agriculture Accredited by Ditjen Penguatan Risbang No.60/E/KPT/2016
J. Indonesian Trop. Anim. Agric. pISSN 2087-8273 eISSN 2460-6278 http://ejournal.undip.ac.id/index.php/jitaa 46(4):356-363, Decemberr 2021

\title{
Pricing of livestock products in Indonesian modern food retailers during covid-19 pandemic
}

\author{
R. Pambudy*, A. K. Adhi, H. Herawati and H. Harianto \\ ${ }^{a}$ Department of Agribusiness, Faculty of Economics and Management, IPB University \\ Jl. Kamper, Kampus IPB Darmaga Bogor 16680, Indonesia \\ *Corresponding E-mail: rachmatpa@apps.ipb.ac.id
}

Received March 5, 2021; Accepted September 11, 2021

\begin{abstract}
ABSTRAK
Peran pasar modern semakin meningkat dalam sistem pangan di Indonesia, terutama akibat dari perkembangan teknologi dan kelembagaan. Konsumsi pangan rumah tangga Indonesia masih bergantung pada makanan pokok. Porsi pengeluaran rumah tangga untuk daging, telur, dan susu hanya 12 persen.. Penelitian ini bertujuan untuk menganalisis penetapan harga produk ternak pada tingkat eceran di pasar modern. Data yang digunakan dalam penelitian ini adalah data harga harian daging sapi, telur, dan ayam di tingkat grosir dan eceran yang diterbitkan melalui Pusat Informasi Harga Pangan Strategis Nasional (PIHPSN) dari Januari 2020 sampai Desember 2020. Penelitian ini menggunakan metode kuantitatif, yaitu dengan membangun model ekonometrika dan kemudian diestimasi dengan menggunakan metode 3SLS. Hasil penelitian menunjukkan bahwa pedagang eceran menerapkan stabilisasi harga di tingkat konsumen pada saat harga di tingkat wholesaler berfluktuasi. Namun penelitian tidak menemukan praktik memeratakan harga antar komoditas di tingkat pengecer. Hasil studi ini berguna untuk perumusan kebijakan yang bertujuan untuk stabilisasi harga pangan.
\end{abstract}

Kata Kunci : 3SLS, Ayam, Daging sapi, Pemerataan harga

\begin{abstract}
The role of modern markets is increasing in the food system in Indonesia, mainly as a result of technological and institutional advances. Indonesian households' food consumption still depends on staple food. The share of household expenditure on meat, eggs, and milk was only 12 percent. The purpose of the study was to analyze the pricing of livestock products in retail level in the modern market. The data used in this study is daily price data for beef, eggs, and chicken at wholesale and retail levels published through the National Strategic Food Price Information Center (PIHPSN) from January 2020 to December 2020. This study employed a quantitative method, through the formulation of an econometric model, and applied the 3SLS method to estimate the model. The results show that traders face an increasing price risk following the Covid-19 pandemic. The retailers enforce price stabilization at the consumer level when prices at the wholesaler level fluctuate. However, the study did not find the practice of price averaging between commodities at the retailers level. The results of this study are useful for policy formulations aimed at stabilizing food prices..
\end{abstract}

Keywords: 3SLS, Beef, Chicken, Price levelling 


\section{INTRODUCTION}

Indonesian households' food consumption still relies on staple food, which is generally high in calories but low in high-quality nutrients. The share of household expenditure on staple food is around 30 percent, while the share of expenditure on meat, eggs, and milk is only 12 percent (Wardhani, 2017). Livestock products are an essential source of protein. The people's per capita protein consumption is still low and far from the expected ideal intake (Faharuddin et al., 2017; Ariani et al., 2018). Protein consumption is unequal when viewed from its relationship with income levels. Households classified as high incomes consume protein from animal products much more than households with lower income groups. Likewise, households in urban areas consume livestock products higher than households in rural areas (Muzayyanah et al., 2013). Consumer access to livestock products can be obtained through purchases at various retail outlets. In many developed countries, consumers buy fresh or unprocessed livestock products from modern markets. Thus, the modern market's development influences the public's health conditions, especially nutrition adequacy (Pulker et al., 2019).

One form of change in the food system in developing countries is the increasing role of supermarkets or modern retails in the supply chain for food products (Reardon and Hopkins, 2006). Although traditional markets in developing countries still have a significant role in delivering livestock products to consumers, the growing supermarket phenomenon is increasingly essential. The increase in household income and the demand for quality products have encouraged modern retail markets' growth (Staal, 2015)

The characteristics of sellers in modern markets are different from those in traditional markets. Small-scale businesses characterize traditional market retailers, low capital endowment, informal business nature, and the buying and selling process allows for bargaining. Retailers in modern markets generally operate in supermarkets, self-service mini shops, products with precise quality standards, formal business in nature, and no bargaining process occurs in the purchasing process. Prices are listed on the packaging of products or on the shelf where the product is displayed. The quality of food products in modern retail markets is generally higher than the quality of food products in traditional markets (Schipmann and Qaim, 2011).

Modern food retailers can be said to be multiproduct firms ( $\mathrm{Li}$ and Sexton, 2013). Changes in product prices need to pay attention to conditions of market demand and competitor reactions (Cant et al., 2016) and take into account the costs that arise from these price changes. When deciding product price, retailers prefer to give the impression of a stable price. They perceive consumers prefer a stable price. Retailers try to partially mask the variability of prices by keeping the selling price relatively unchanged in price fluctuations at the level of the supplier of the product. To make that selling prices do not change when prices of products from suppliers change, retailers make adjustments in marketing margins. Retailers can also make the impression of stable product prices by averaging the selling prices of various goods being sold. Averaging can be done by maintaining the marketing margin of one product while increasing the marketing margin.

The livestock products selected in this study are beef, chicken eggs, and chicken meat. These three livestock products are important sources of protein, and from the consumer's point of view, they can be mutually substituted. This research was conducted at the time of the Covid19 pandemic, which had not yet subsided in Indonesia. The vaccination program to prevent the spread of SARS-Cov-2 is still running in the first phase, and a small number of the population is being vaccinated. The nature of the SARS-Cov2 virus, which is easily spread through various means of human contact (Liu et al., 2020; Chan et al., 2020; Huang et al., 2020), has led to government policies to limit people's economic activities. Experience in various countries, the Covid-19 pandemic has significantly disrupted the supply chain of agricultural products (Urumugam et al., 2020; Pan et al., 2020; Huang, 2020). Therefore, this study includes a variable to capture whether there is an effect of the Covid-19 pandemic on the retail trader pricing strategy.

At a certain level, each seller in the modern market does not fully act as a price taker. The same or identical food products are not necessarily sold at the same price by all sellers in the modern market. The price difference is caused by differences in product quality or characteristics and various marketing functions provided by the seller and determined by the outlet type 
(Caspi et al., 2017). This study aimed to analyze the pricing practices of essential livestock products, namely beef, chicken eggs, and chicken meat, in the modern market. Modern markets have long been present in developing countries (Reardon et al., 2003), but research related to pricing practices in modern markets in Indonesia, especially livestock products, is still challenging to find. This research's main contribution is expected to come from its ability to explain the phenomenon of pricing behavior in the modern retail market for livestock products. The results of this study are expected to be useful for the formulation of government policies aimed at stabilizing the price of livestock products at the consumer level, and of course, also policies that have implications for the welfare of producers because the pricing strategy carried out by sellers at the retail level will be transmitted to the producer level.

\section{MATERIALS AND METHODS}

This study uses daily price data for beef, egg, and chicken farm products to test the proposed hypothesis. The data period is from January 2020 to December 2020. All product prices at the wholesaler and retailer level have been converted into the same weight measurement, namely IDR per kilogram. Data comes from the Central Bank of Indonesia (BI). Daily data on livestock products, meat, eggs, and chicken are part of the price recording by BI for food items that are considered strategic, especially in their effect on the inflation rate. This data is regularly published on the National Strategic Food Price Information Center (PIHPSN).

The research model has three equations, with each dependent variable is price spread beef, price spread egg, and price spread chicken. This study assumes that retail traders are multiproduct firms, so price decisions for other products also influence those price decisions for one commodity. Therefore, the three equations are considered a simultaneous equation or the seemingly unrelated regression equations (SURE) model. In the basic SURE model, each error in the equation is considered homoscedastic and linearly independent. In this study, the error in each equation may correlate with one another over the same period. To avoid contemporaneous correlation, the 3SLS (three-stage least square) estimation method was used. Simultaneous method, such as 3SLS, also more appropriate for obtaining a consistent and efficient coeffecient estimate (Judge et al., 1985).

The research model adopted from Griffith et al. (1992) model and can be presented in the following equation:

$$
\begin{gathered}
P S_{B}=\propto_{0}+\propto_{1} P W_{B}+\propto_{2} L P W_{B}+\propto_{3} P S_{E}+\propto_{4} P S_{C} \\
+\propto_{5} L P S_{B}+\alpha_{6} \operatorname{COVID} \\
P S_{E}=\beta_{0}+\beta_{1} P W_{E}+\beta_{2} L P W_{E}+\beta_{3} P S_{B}+\beta_{4} P S_{C} \\
+\beta_{5} L P S_{E}+\beta_{6} \operatorname{COVID} \\
P S_{C}=\gamma_{0}+\gamma_{1} P W_{C}+\gamma_{2} L P W_{C}+\gamma_{3} P S_{B}+\gamma_{4} P S_{E} \\
+\gamma_{5} L P S_{C}+\gamma_{6} \operatorname{COVID}
\end{gathered}
$$

Where,

$P S$ : Price spread (Retail price - Wholesale price)

$P W \quad$ : Wholesaler price

$L P W$ : Wholesale price lagged one period

$L P S \quad$ : Price spread lagged one period

COVID : dummy variable $(C O V I D=0$, before government implementing Large-Scale Social Restrictions (PSBB) at 10 April 2020; COVID $=1$, otherwise)

Subscript $B, E$, and $C$ : stand for beef, egg, and chicken.

If retail traders employ the price stabilization strategy for the three livestock products, the hypothesis tested in this study is that each product price at the wholesale level has a negative and significant effect on marketing margins or price spreads, or the regression coefficients $\alpha_{1}$, $\beta_{1}$, and $\gamma_{1}$ smaller than 0 . The effect of the price lag of one period at the wholesale level is positive, and the coefficients $\alpha_{2}, \beta_{2}$, and $\gamma_{2}$ are positive. If the price trend at the wholesale level increases, the price spread expands to balance the previous period's influence. So that in the long run, prices at the retail level follow the same trend as the prices trend at the wholesale level. The hypothesis for the practice of price averaging is that the effect of other product price spreads is negative, or in other words, the variable coefficients of $\mathrm{PS}_{\mathrm{B}}, \mathrm{PS}_{\mathrm{E}}$, and $\mathrm{PS}_{\mathrm{C}}$ are negative $\left(\alpha_{3}, \alpha_{4}, \beta_{3}, \beta_{4}, \gamma_{3}\right.$, and $\left.\gamma_{4}<0\right)$. If the price spread of other products increases (independent variable), then the product price spread (dependent variable) will decrease, resulting in an even distribution of all products' prices. The lag variable price spread for one period is included in the model based on the assumption of partial adjustment. In this study, daily data is used so that changes in marketing margins due to changes in the independent variables do not occur immediately, so there is still an influence from the previous marketing margin values in determining current mar- 
keting margins. Alternatively, the regression coefficients $\alpha_{5}, \beta_{5}$, and $\gamma_{5}$ are positive. The sign of the COVID-19 dummy variable cannot be determined a priori because, during the Covid-19 pandemic, marketing costs change, but retailers could change their profit margins that the final result of marketing margins could be positive or negative.

The data employed in this study was a time series. However, if the time series data is not stationary, then the regression model used can produce spurious regression (von CramonTaubadel, 2017). Spurious regression is a condition in which there is a statistically significant long terms relationship between variables in the regression model when in fact all that obtained is only proof of a contemporary correlation rather than a meaningful cause-and-effect relationship (Harris \& Sollis, 2003). To ensure that the data meet the stationarity requirements, an Augmented Dicky-Fuller Unit Root Test (ADF test) was carried out on the data of dependent variables in the model (Asteriou \& Hall, 2011). In the ADF test, the null hypothesis is that there is a unit root in the data, or the data is not stationary.

\section{RESULTS AND DISCUSSION}

\section{Price and Price Spread Dynamics}

Based on the theory, food prices at each market level are directly affected by demand conditions and market structure. The demand for a product at the retail market level is direct, while the market demand below can be derivative. Table 1 shows the conditions of average price and price spread at the wholesale level and the retail level in the modern market, along with their coefficient of variation. It appears that the average price of livestock products at the level of wholesalers has increased slightly during the Covid-19 pandemic when compared to before the implementation of the regional lockdown policy. The price increase at the wholesale level was also accompanied by an increase in prices at the retail level for meat and chicken. However, the retail price of eggs increased slightly. Except for beef prices, the coefficient of variation in egg and chicken prices at the retail level is relatively smaller than the coefficient of variation at the wholesale level. Likewise, except for beef, the coefficient of price variations in the egg and chicken markets increased during the Covid-19 epidemic. This is an indicator of the increasing price risk that traders face during this pandemic.

Based on Table 1, the price spread for the beef market has remained relatively unchanged during the Covid-19 pandemic. On the other hand, there was an increase in the egg and chicken market price spread. Besides the increasing price spread, the coefficient of variation of the egg and chicken market price spread also increased. The coefficient of variation in price spread in the beef market decreases. Contrary to the early expectation, the disruption in the entry of feeder cows and frozen meat from abroad due to Covid-19 seems to have resulted in a more stable beef market at the consumer and wholesaler level. The domestic meat market seems relatively isolated from the global market's problems due to the Covid-19 pandemic. At the global level, the Covid-19 pandemic, which was followed by restrictions on human activities, resulted in disruption of economic

Table 1. Mean and Coefficient Variation of Livestock Products Prices and Price Spreads at Retail and Wholesale Levels

\begin{tabular}{|c|c|c|c|c|}
\hline \multirow{2}{*}{$\begin{array}{l}\text { Products, Price, and } \\
\text { Price Spread }\end{array}$} & \multicolumn{2}{|c|}{ Before Covid-19 Pandemic } & \multicolumn{2}{|c|}{ During Covid-19 Pandemic } \\
\hline & Mean (IDR) & $\mathrm{CV}^{*}(\%)$ & Mean (IDR) & $\mathrm{CV}^{*}(\%)$ \\
\hline \multicolumn{5}{|l|}{ Beef } \\
\hline 1. Wholesale price & 110997 & 0.2 & 111407 & 0.4 \\
\hline 2. Retail price & 147099 & 0.9 & 147513 & 0.7 \\
\hline 3. Price spread & 36101 & 4.1 & 36105 & 2.9 \\
\hline \multicolumn{5}{|l|}{ Egg } \\
\hline 1. Wholesale price & 22932 & 2.3 & 22960 & 5.3 \\
\hline 2. Retail price & 27980 & 1.0 & 27880 & 3.1 \\
\hline 3. Price spread & 5047 & 8.0 & 4920 & 13.9 \\
\hline \multicolumn{5}{|l|}{ Chicken } \\
\hline 1. Wholesale price & 26463 & 2.9 & 27231 & 9.7 \\
\hline 2. Retail price & 37703 & 1.1 & 38376 & 3.6 \\
\hline 3. Price spread & 11244 & 6.5 & 11145 & 18.6 \\
\hline
\end{tabular}

*Coefficient Variation $(\mathrm{CV})=$ Standard Deviation/Mean x 100\% 
Table 2. The Results of the ADF Test on the Dependent Variables.

\begin{tabular}{lccc}
\hline Variable & Test Statistics & $1 \%$ Critical Value & MacKinnon Approximate p-value \\
\hline $\mathrm{PS}_{\mathrm{B}}$ & -8.828 & -3.461 & 0.0000 \\
$\mathrm{PS}_{\mathrm{E}}$ & -7.288 & -3.461 & 0.0000 \\
$\mathrm{PS}_{\mathrm{C}}$ & -7.567 & -3.461 & 0.0000 \\
\hline
\end{tabular}

Table 3. The Goodness of Fit of the Research Model

\begin{tabular}{|c|c|c|c|}
\hline Equation & R-square & Chi-square & $\mathrm{P}$ \\
\hline $\mathrm{PS}_{\mathrm{B}}$ & 0.7784 & 886.89 & 0.0000 \\
\hline $\mathrm{PS}_{\mathrm{E}}$ & 0.9363 & 3651.95 & 0.0000 \\
\hline $\mathrm{PS}_{\mathrm{C}}$ & 0.9785 & 11227.16 & 0.0000 \\
\hline
\end{tabular}

activity throughout the world, especially in the agricultural sector, both on the production side, the marketing chain, and on the consumption side (Siche, 2020; Poudel et al., 2020). Indonesia still depends on imported meat to cover the shortage of supply from domestic meat producers. Although the impact differs between countries (Grinberga-Zalite et al., 2021; Aday \& Aday, 2020), the problems faced by supply chains in the global market may eventually impact the domestic meat market when the stock of feeder cattle and frozen meat currently at the producer and wholesaler levels is running low.

\section{Pricing at the Retail Level}

Before regressing the research model, it was necessary to find out whether the data used in the model is stationary. The ADF test was carried out on the dependent variable data in the model. Based on the results of the ADF test presented in Table 2, it can be seen that the null hypothesis was rejected, meaning that the data is stationary. The value of Dicky-Fuller test statistics for each tested variable is far beyond 1 percent of the critical value. The greater the negative value of the DF test statistic, the stronger the evidence to reject the null hypothesis. This is also supported by MacKinnon's approximate p-value which is much less than 1 percent.

Based on the estimation results using the 3SLS, it can be seen in Table 3 that the model has high goodness of fit, especially in the equations for egg and chicken. The R-square value of the price spread equation for eggs and chicken is greater than 90 percent. The model can explain price spread variations in the egg and chicken markets above 90 percent. As for the beef price spread equation, the model can explain the price variations by 77 percent. Based on the significance test using the Chi-square indicator, it appears that all the independent variables in each equation simultaneously have a significant effect on the price spread (dependent variable), as indicated by a P-value of less than 1 percent.

Estimates for the price spread model of beef, egg, and chicken show results following the research hypothesis, especially in terms of the regression coefficient sign. The price of livestock products at the wholesale level $\left(P W_{B}, P W_{E}\right.$, $\left.P W_{C}\right)$ has a negative and significant effect on price spread $\left(P S_{B}, P S_{E}, P S_{C}\right)$ in each equation in the model. These results indicate that pricing practices at the retail level attempt to stabilize the selling price. When the wholesaler's price increases, the retailers reduce the price spread so that the product's selling price does not increase as much as the price increase at the wholesale level. Retailers seek to reduce fluctuations in the selling price of products to consumers by increasing or decreasing the price spread. The practice of price stabilization carried out by retailers certainly has a positive effect on consumers and sellers, namely in the form of a decrease in price risk faced (Grega, 2018). The practice of price stabilization by retailers is also something that the government intended. Employing the phenomenological method, the research of Susila et al. (2020) found that the local government asked beef distributors to reduce profits so that prices were stable and avoided price spikes.

Based on the estimation results listed in Table 4, it can be seen that the marginal effect of each price change at the wholesale level on the price spread is quite large. For every 1 IDR increase in the price at the beef wholesaler level, the price spread will decrease by -1.08 IDR. As for the price spread in the egg and beef market, the marginal effects are -0.92 IDR and 0.91 IDR (rounded numbers), respectively. To compare the sensitivity of price spread changes to price changes at the wholesale level for each product, a comparison of the magnitude of its elasticity can be employed. If calculated based on the mean of price and the mean of price spread, the 
elasticities for beef, eggs, and chicken will be obtained of $-3.3,-4.1$, and -2.12 , respectively. This shows that the price spread in the egg market is the most sensitive to price changes at the wholesale level. If the price of eggs at wholesalers increases by 1 percent, then the price spread between retailer and wholesalers will contract by 3.3 percent.

It is presumed that the difference in the sensitivity to changes in price spread is partly determined by the price elasticity of the demand being faced. Demand elasticity has an important role in pricing (Yousefi et al., 2011; Petricek et al., 2020). Using data from the National SocioEconomic Survey for NTB and NTT provinces (Suryana et al., 2019) found that the price elasticity of demand for beef, egg, and chicken were $0.22,-0.82$, and -0.87 , respectively. The less elastic product demand allows for a relatively highprofit margin setting. A higher profit margin can be translated into higher retailers' flexibility to reduce profit or reduce price spread to prevent customers' loss when prices at the wholesale level rise.

The model estimation results in Table 4 also show that prices at the whole salers level in the previous period significantly affect the price spread. Except for beef, the variable price lag at the wholesale level on the price spread is posi- tive. This shows that the retail level's price trend is in line with price movements at the wholesale level. On the other hand, the price trend at the retail level of beef is opposite to the price trend at the wholesale level. The possibility of this difference arises because eggs and chicken rely on supplies from domestic production, while the meat is more dependent on foreign supplies, both in the form of feeder cows and frozen meat. This condition is also supported by the data in Table 1 , where the coefficient of price variations at the level of wholesalers and retailers for eggs and chicken has increased during the Covid-19 pandemic.

On the other hand, the coefficient of price variations at the wholesalers and retailer's beef markets fell during the pandemic compared to the period before. The phenomenon of the price spread in the beef market, which is different from the price spread in the egg and chicken markets, is also seen in the independent variable's effect on the previous price spread (lag price spread). The regression coefficient for $\mathrm{LPS}_{B}$ is negative, while the regression coefficient for $\mathrm{LPS}_{E}$ and $\mathrm{LPS}_{C}$ is positive. The positive regression coefficient indicates that retailers have adjusted the price spread in the same direction as the previous value.

However, this study did not find a signifi-

Table 4. The Results of Model Estimation

\begin{tabular}{|c|c|c|c|c|}
\hline Equation & Coefficient & Standard Error & $\mathrm{Z}$ & $\mathrm{P}>|\mathrm{z}|$ \\
\hline \multicolumn{5}{|c|}{ Price Spread of Meat } \\
\hline $\mathrm{PW}_{\mathrm{B}}$ & -1.079125 & 0.1630953 & -6.62 & 0.000 \\
\hline $\mathrm{LPW}_{\mathrm{B}}$ & 1.09392 & 0.1684213 & 6.47 & 0.000 \\
\hline $\mathrm{PS}_{\mathrm{E}}$ & -0.0516377 & 0.0594679 & 0.87 & 0.385 \\
\hline $\mathrm{PS}_{\mathrm{C}}$ & -0.0033182 & 0.0205294 & 0.16 & 0.872 \\
\hline $\mathrm{LPS}_{\mathrm{B}}$ & -0.8958828 & 0.0312603 & 28.66 & 0.000 \\
\hline COVID & 2.207704 & 87.80562 & 0.03 & 0.980 \\
\hline Constant & 2817.174 & 10285.8 & 0.27 & 0.784 \\
\hline \multicolumn{5}{|c|}{ Price Spread of Egg } \\
\hline $\mathrm{PW}_{\mathrm{E}}$ & -0.9168337 & 0.0538761 & -17.02 & 0.000 \\
\hline $\mathrm{LPW}_{\mathrm{E}}$ & 0.8871575 & 0.0543729 & 16.32 & 0.000 \\
\hline $\mathrm{PS}_{\mathrm{B}}$ & -0.0043831 & 0.0099198 & -0.44 & 0.659 \\
\hline $\mathrm{PS}_{\mathrm{C}}$ & -0.0079666 & 0.0057961 & -1.37 & 0.169 \\
\hline $\operatorname{LPS}_{\mathrm{E}}$ & 0.8733868 & 0.0236263 & 36.97 & 0.000 \\
\hline COVID & -18.56744 & 22.55808 & -0.82 & 0.410 \\
\hline Constant & 1574.187 & 479.0483 & 3.29 & 0.001 \\
\hline \multicolumn{5}{|c|}{ Price Spread of Chicken } \\
\hline $\mathrm{PW}_{\mathrm{C}}$ & -0.9072518 & 0.0423881 & -21.40 & 0.000 \\
\hline $\mathrm{LPW}_{\mathrm{C}}$ & 0.873266 & 0.0432102 & 20.21 & 0.000 \\
\hline $\mathrm{PS}_{\mathrm{B}}$ & -0.0523179 & 0.0420402 & -1.24 & 0.213 \\
\hline $\mathrm{PS}_{\mathrm{E}}$ & 0.0185844 & 0.0193961 & 0.96 & 0.338 \\
\hline $\mathrm{LPS}_{\mathrm{C}}$ & 0.9195838 & 0.0210475 & 43.69 & 0.000 \\
\hline COVID & 61.88765 & 42.89885 & 1.44 & 0.149 \\
\hline Constant & 7169.595 & 4596.708 & 1.56 & 0.119 \\
\hline
\end{tabular}


cant price averaging phenomenon at the livestock products market's retail level. Although the coefficient of the independent variable price spread is generally negative, it is not statistically significant. When examined and using the 20 percent significance benchmark and using a one-way test, there seems to indicate that the chicken market's price spread negatively affects the egg market's price spread. Likewise, the beef market's price spread negatively influences the price spread of the chicken market.

Table 4 also shows that the Covid-19 pandemic has no real effect on price spreads across all the commodities studied. Traders in the modern market in Indonesia did not seem to feel the urge to make changes to their pricing strategy. While in developed countries, the Covid-19 pandemic already has a negative impact on the supply chain of agricultural products. Problems in developed countries arise due to the difficulty of finding labor and the number of agricultural companies that reduce their production levels (Devereux et al., 2020). Changes also occur at the consumer level (Cranfield, 2020), and it is estimated that changes on the consumer side will have more influence on price policy at the retail level in the modern market. Pricing behavior in modern markets in Indonesia is also expected to change as the impact of the Covid-19 pandemic deepens.

\section{CONCLUSION}

The average price of livestock products at the wholesale and retail levels in modern markets has not shown a significant change during the Covid-19 pandemic. Likewise, the average price spread between the retail market and the wholesale market did not change significantly. However, during this pandemic period, there was an increase in price variability at wholesalers and retailers, especially in the egg and chicken markets. The Covid-19 pandemic has increased the price uncertainty faced by both wholesalers and retailers of livestock products. Statistically, the Covid-19 pandemic has no significant effect on the price spread of livestock products. Prices influence the price spread at the level of wholesalers and the price spread of the previous period. This study found that livestock products' retailers practiced price stabilization but did not find any significant price averaging among various livestock products. This behavior of pricing at the retail level in the modern market for livestock products has important government policy implications towards price stabilization at the consumer level.

\section{REFERENCES}

Aday, S. and M.S. Aday. 2020. Impact of covid19 on the food supply chain. Food Quality and Safety. 4(4): 167-180.

Ariani, M., A. Suryana, S. H. Suhartini, and H. P. Saliem. 2018. Performance of animal food consumption based on region and income at household level. J. Analisis. Keb. Pert. 16 (2): 147-163.

Asteriou, D. and S.G. Hall. 2011. Applied Econometrics $\left(2^{\text {nd }}\right.$ ed.). Palgrave Macmillan. New York.

Cant, M. C., J. Wiid, and C. M. Shepapo. 2016. Key Factors Influencing Pricing Strategies for Small Business Enterprises (SMEs): Are They Important?. J. App. Bus. Res. 32 (6): 1737-1750.

Caspi, C. E., J. E. Pelletier, L. J. Harnack, D. J. Erickson, K. Lenk, and M. N. Laska. 2017. Pricing of staple foods at supermarkets versus small food stores. Intl. J. Env. Res. Pub. Heal. 14(8): 915.

Chan, JF-W., S. Yuan, K-H. Kok, KK-W. To, H. Chu, and J. Yang. 2020. A familial cluster of pneumonia associated with the 2019 novel coronavirus indicating person-toperson transmission: a study of a family cluster. Lancet. 395: 514-523.

Cranfield, J. A. L. 2020. Framing consumer food demand responses in a viral pandemic. Canadian Journal of Agricultural Economics, 68: 151-156.

Devereux, S., C. Béné, and J. Hoddinott. 2020. Conceptualising COVID-19's impacts on household food security. Food Security. 12: 769-772.

Faharuddin, F., A. Mulyana, M. Yamin, and Y. Yunita. 2017. Nutrient elasticities of food consumption: the case of Indonesia. J. Agr. Dev. Emer. Eco. 7(3): 198-217.

Grega, L. 2018. Price stabilization as a factor of competitiveness of agriculture. Agricultural Economics (Zemědělská ekonomika). 48: 281-284.

Griffith, G.R., W. E. Jamandre, and R. R. Piggott. 1992. A note on price levelling and price averaging in sydney retail vegetable price spreads. Rev. Mark, Agri. Econ. 60: 43-55. 
Grinberga-Zalite, G., I. Pilvere, A. Muska, and Z. Kruzmetra. 2021. Resilience of meat supply chains during and after COVID-19 crisis. Emerg. Sci. J. 5: 57-66.

Harris, R. and R. Sollis. 2003. Applied Time Series Modelling and Forecasting $\left(1^{\text {st }}\right.$ ed.). Hoboken, NJ: Wiley. Chichester, West Sussex, England.

Huang, C., Y. Wang, X. Li, L. Ren, J. Zhao, Y. Hu. 2020. Clinical features of patients infected with 2019 novel coronavirus in $\mathrm{Wu}-$ han, China. Lancet. 395: 497-506.

Huang, J. 2020. Impacts of COVID-19 on agriculture and rural poverty in China. J. Integ. Agri. 19(12): 2849-2853.

Judge, G.G., W.E. Griffiths, R.C. Hill, H. Lutkhephol, and T-C. Lee. 1985. The Theory and Practice of Econometrics ( $2^{\text {nd }}$ ed.). John Wiley and Sons. New York.

Li, C., and R. J. Sexton. 2013. Grocery-retailer pricing behavior with implications for farmer welfare. J. Agri. and Res. Econ. 141-158.

Liu, J., X. Liao, S. Qian, J. Yuan, F. Wang, Y. Liu. 2020. Community transmission of Severe Acute Respiratory Syndrome Coronavirus 2, Shenzhen, China, 2020. Emerg. Infec. Dise. 26 (6): 1320-1323.

Muzayyanah, M. A. U., S. Nurtini, and S. P. Syahlani. 2014. Household budget and calorie consume of livestock products: evidence from Indonesia. Acad. Res. Intl. 5(3): 174-179.

Pan, D., J. Yang, G. Zhou, and F. Kong. 2020. The influence of COVID-19 on agricultural economy and emergency mitigation measures in China: A text mining analysis. Plos. One. 15(10).

Petricek, M., S. Chalupa, and K. Chadt. 2020. Identification of consumer behavior based on price elasticity: a case study of the Prague market of accommodation services. Sustainability. 12(22): 9452.

Poudel, P.B., M. R. Poudel, A. Gautam, S. Phuyal, C. K. Tiwari, N. Bashyal, and S. Bashyal. 2020. COVID-19 and its global impact on food and agriculture. J. Bio. World. 9(5): 221.

Pulker, C.E., G. S. A. Trapp, J. A. Scott, and C. M. Pollard. 2019. The nature and quality of Australian supermarkets' policies that can impact public health nutrition, and evidence of their practical application: a cross-sectional study. Nutrients. 11(4): 853.

Reardon, T. and R. Hopkins. 2006. The supermarket revolution in developing countries: policies to address emerging tensions among supermarkets, suppliers and traditional retailers. The. European J. Dev. Rese. 18: 522-545.

Reardon, T., C. P. Timmer, C. B. Barrett, and J. Berdegué. 2003. The rise of Supermarkets in Africa, Asia, and Latin America. American. J. Agr. Eco. 85(5): 1140-1146.

Schipmann, C. and M. Qaim. 2011. Modern food retailers and traditional markets in developing countries: comparing quality, prices, and competition strategies in Thailand. Appl. Eco. Persp. Pol. 33(3): 345-362.

Siche, R. 2020. What is the impact of COVID-19 disease on agriculture?. J. Sci. Agro. 11 (1): $3-6$.

Staal, S. J. 2015. Livestock marketing and supply chain management of livestock products. Indian J. Agric. Eco. 70(1): 42-63.

Suryana, E.A., D. Martianto, and Y. F. Baliwati. 2019. Pola konsumsi dan permintaan pangan sumber protein hewani di provinsi Nusa Tenggara Barat dan Nusa Tenggara Timur. J. Analisis. Keb. Pert. 17(1): 1-12.

Susila, I., B. Setiaji, H. Wahyudi, A. Setyawan. 2020. Supply chain strategy in stabilization of products price: Case study beef price in Indonesia. International Journal of Supply Chain Management, 9: 1055-1062.

Urumugam, U., G. Kanagavalli, and M. Manida. 2020. Covid-19: Impact of agriculture in India. Aegaeum. J. 8(5): 480-488.

von Cramon-Taubadel, S. 2017. The analysis of market integration and price transmission - results and implications in an African context. Agrekon. 56(2), 83-96.

Wardhani, A. T. 2017. The impact of own produced consumption on rural households' consumption patterns. J. Eko. Kebij. Pub. 8(1): 13-25.

Yousefi, S., M. Moghaddam, and V. Majd. 2011. Optimal real-time pricing in an agentbased retail market using a comprehensive demand response model. J. Ener. 36(9): 5716-5727. 